\title{
REPUDIASI DALAM PEMENUHAN PRESTASI KONTRAK PENGADAAN BARANG/JASA PEMERINTAH
}

\author{
Chrestella \\ stella.hutauruk@gmail.com \\ Dinas Pekerjaan Umum Kota Tarakan
}

\begin{abstract}
Government goods/services is never free from contracts. The contract is the basis of every action / achievement carried out both by the Government as the user of the goods / services and the Provider as the provider of the goods / services. In the process of running a contract is very prone to conflict / dispute between the parties. On average, contract conflicts up to contract disputes take place after the contract expires so that they can be carried out through courts or alternative dispute resolution institutions stipulated in the law. However, teh main point is this study is the contract conflict that has not been a contract dispute because the contract has not ended (the periode of contract execution) or the contract has not started (precontract). Can it be called a default if the contract has not been completed and there are parties who want to cancel the contract? Do the principles of goodfaith and balance apply to contracts where one of the parties is the government?Based on this, the following matters will be examined: 1) The principle of good faith in the government through contract repudiation to prevent breach of contract; 2) The principle of balance in the implementation of contract repudiation of government goods/service procurement. The research method used a normative juridical method with statutory and conceptual approaches. From the results of the study, it was concluded that in the case of the Government with the principle of good faith and proportional balance of contracts through Repudiation efforts trying to prevent harmful things such as defaults when the Government considers that the contract cannot be continued. The value of good faith as the most fundamental basis coupled with balance values in accordance with its portion or the so-called proportional principle must really be the most serious concern in making contracts not only to safeguard the rights and obligations of the parties but more importantly to achieve the purpose of the contract that is the fulfillment of government goods / services.
\end{abstract}

Keywords : Repudiation, governement, contract, good faith, proportional.

\section{PENDAHULUAN}

\section{Latar Belakang}

Sistem pengadaan barang/ jasa Pemerintah diatur dalam Peraturan Presiden yang telah diubah beberapa kali kemudian diperbaharui menjadi 
Perpres No 16 Tahun 2018 Tentang Pengadaan Barang dan Jasa Pemerintah. Menurut Perpres No 16 Tahun 2018 Pasal 1 angka (1) tentang Pengadaan Barang/ Jasa Pemerintah menyebutkan pengadaan barang/jasa pemerintah yang selanjutnya disebut pengadaan barang/jasa adalah kegiatan pengadaan barang/jasa oleh Kementerian/ Lembaga/Perangkat Daerah yang dibiayai oleh APBN/APBD yang prosesnya sejak identifikasi kebutuhan, sampai dengan serah terima hasil pekerjaan.

Lahirnya Perpres Nomor 16 Tahun 2018 tentang Pengadaan barang/jasa Pemerintah melahirkan paradigma baru pengadaan barang dan jasa pemerintah dimana menghapus seluruh peraturan pemerintah sebelumnya terkait Pengadaan Barang dan Jasa Pemerintah. Perpres No 16 Tahun 2018 ini sebagai jawaban dari tantangan dunia yang telah memasuki era disrupsi teknologi dimana fenomena Internet of Thing, big data, cloud computing hingga artificial intelegent yang telah menjadi bagian yang mendukung aktivitas seluruh elemen masyarakat ${ }^{1}$.Di sisi lain disrupsi teknologi juga mentransformasi organisasi pemerintah dengan memotong rantai birokrasi, memudahkan prosedur, dan mengubah pola kerja yang bertujuan agar organisasi lebih responsif, transparan dan accessible sehingga terjadi "check and balance" dalam sistem pengadaan barang/jasa.

Perpres No 16 Tahun 2018 tentang Pengadaan Barang/Jasa Pemerintah ini juga semakin mendorong value for money terhadap hasil pengadaan barang/jasa dengan tidak lagi menjadikan harga termurah menjadi tolak ukur efektivitas pengadaan barang/jasa. Perubahan pola bisnis dan aktivitas pasar tersebut juga membawa perubahan terhadap kebutuhan sumber daya manusia sebagai pengelola dan unit pengelola pengadaan yang dituntut untuk lebih profesional dan memiliki kompetensi khusus maupun kompetensi teknis dalam bidang pengadaan barang/jasa.

Hubungan kontraktual sebagai dasar pemerintah dan penyedia melakukan kegiatan pengadaan barang/jasa pemerintah adalah Perjanjian tertulis antara

\footnotetext{
1 1Siaran Pers Paradigma Baru Pengadaan Barang/Jasa Pemerintah, http://www.lkpp.go.id/v3/\#/read/5446, diakses tanggal 23 Juli 2019 (19.00).
}

99 | Pasca Sarjana Magister Hukum Universitas Borneo Tarakan 
pengguna anggaran (PA)/ kuasa pengguna anggaran (KPA)/ Pejabat Pembuat Komitmen (PPK) dengan penyedia barang/jasa atau pelaksanaan swakelola. Dalam kontrak pengadaan barang/jasa pemerintah, Pejabat Pembuat Komitmen atau yang disingkat dengan PPK bertugas menetapkan rancangan kontrak dan mengendalikan kontrak, sementara pihak penyedia bertanggung jawab atas pelaksanaan kontrak. Kedua belah pihak sama-sama memiliki tujuan dan kepentingan yang saling mendukung serta berlandaskan pada prinsip-prinsip umum kontrak dan tunduk pada peraturan perundang-undangan. Sehingga prinsip itikad baik dan keseimbangan proporsional menjadi hal yang sangat penting bahkan melekat dari tahap pra kontraktual (tahap penawaran), kemudian saat muncul kesepakatan yang menimbulkan perikatan antara para pihak (tahap kontraktual), sampai kepada tahap pelaksanaan perjanjian yang mengingat para pihak bahkan hingga berakhirnya kontrak.

Menurut hukum Indonesia bahwa pembatalan perjanjian merupakan suatu konsekuensi apabila salah satu pihak ingkar janji (wanprestasi). KUHPerdata Pasal 1266 dan 1267 mengatur bahwa pembatalan perjanjian tidak batal demi hukum melainkan harus dimintakan kepada pengadilan meskipun syarat batal mengenai tidak dipenuhinya kewajiban dinyatakan dalam perjanjian, dan pihak yang merasa dirugikan dapat menuntut dengan pilihan memaksa pihak lain untuk memenuhi perjanjian atau menuntut pembatalan perjanjian dengan pergantian biaya, kerugian dan bunga. Pasal ini tidak diperbolehkan untuk dikesampingkan sesuai Putusan MA Nomor 2821K/Pdt/2009 yang menyebutkan dalam pertimbangannya menyatakan suatu perjanjian yang mengesampingkan pasal tersebut bertentangan dengan keadilan dan asas itikad baik.

Rata-rata konflik kontrak hingga menjadi sengketa kontrak berlangsung setelah kontrak berakhir sehingga pelaksanaan nya dapat melalui pengadilan atau lembaga alternatif penyelesaian sengketa yang diatur dalam undang-undang. Namun, poin utama dalam pembahasan kali ini adalah bagaimana untuk konflik kontrak yang belum menjadi sengketa kontrak dikarenakan kontrak belum berkahir (masa pelaksanaan kontrak) ataupun kontrak belum dimulai (pra

\section{0 | Pasca Sarjana Magister Hukum Universitas Borneo Tarakan}


kontrak). Apakah bisa dikatakan wanprestasi jika kontrak belum selesai dan ada pihak yang ingin membatalkan kontrak? Apakah prinsip Itikad baik dan keseimbangan berlaku terhadap kontrak yang salah satu pihaknya Pemerintah?

Literatur yang beredar dalam dunia keperdataan Indonesia sangat jarang menyebutkan Repudiasi dalam penyelesaian kontrak yang masih dalam masa pelaksanaan dan tidak dapat dilaksanakan lagi. Jika melihat dari sumber-sumber bebas di dunia daring (dalam jaringan) maka repudiasi sering dikaitkan dengan pembatalan perjanjian sepihak. Pembatalan perjanjian disini dimaksudkan membawa kedua belah pihak kembali pada keadaan sebelum perjanjian diadakan. Pembatalan. Namun pembatalan perjanjian melalui konsep respudiasi dalam hal ini memiliki konsekuensi yuridis, terkait dengan kontrak pemerintah yang notabene nya bukan lah kontrak biasa yang begitu mudah dilakukan repudiasi kemudian kontrak dibatalkan. Terlebih dalam pembahasan kali ini yang melakukan repudiasi adalah pihak dari Pemerintah. Perlu dikaji mekanisme hukum dengan memperhatikan dasar-dasar hukum yang berlaku di Indonesia. Jikalapun repudiasi ini dilakukan baik oleh pihak pemerintah atau penyedia, harus mengedepankan prinsip itikad baik dan keseimbangan.

Penulisan kali ini akan membahas lebih banyak dari sisi pemerintah sebagai pihak yang melakukan repudiasi semata-mata untuk menyelamatkan kontrak bukan malah pembatalkan secara sepihak, ada unsur mencegah wanprestasi karena usaha pemerintah ini dilakukan dalam rangka mencegah wanprestasi itu sendiri bahkan mencegah terjadinya kontrak gagal. Tentu saja, repudiasi yang dilakukan pemerintah memiliki karakteristik yang berbeda dengan repudiasi yang dilaksanakan oleh pihak-pihak biasa. Harus ada keseimbangan proporsional didalamnya antara Pemerintah sebagai pihak yang mana memiliki tujuan semata-mata memenuhi kebutuhan masyarakat luas dalam artinya ada kepentingan publik di dalamnya meski kontrak dilaksanakan berdasarkan hukum privat dengan Penyedia yang mewakili dirinya sendiri dalam rangka pemenuhan kebutuhan bisnis dan murni berdasarkan hukum privat karena bertindak atas dasar dirinya sendiri. Oleh karena perlunya pemahaman dan pembahasan

\section{1 | Pasca Sarjana Magister Hukum Universitas Borneo Tarakan}


lebih mendalam lagi terhadap isu yang coba diangkat maka penulis ingin mengkaji lebih dalam lagi mengenai Repudiasi Dalam Pemenuhan Prestasi Kontrak Pengadaan Barang/Jasa Pemerintah.

\section{B. Rumusan Masalah}

Rumusan masalah dalam penulisan ini adalah bagaimana prinsip itikad baik pemerintah melalui repudiasi kontrak untuk mencegah wanprestasi kontrak dan bagaimana prinsip keseimbangan dalam pelaksanaan repudiasi itu sendiri.]

\section{Metode Penelitian}

Penelitian ini merupakan penelitian yang bersifat yuridis normatif. Tipe penulisan yuridis normatif merupakan penelitian untuk menemukan aturan hukum, prinsip-prinsip hukum, maupun doktrin-doktrin hukum guna menjawab isu hukum yang dihadapi. Pendekatan yang digunakan dalam penelitian ini menggunakan pendekatan perundang-undangan (statute approach) dan pendekatan konseptual (conceptual approach). Bahan hukum yang digunakan sebagai dasar untuk menunjang hasil penelitian meliputi seluruh peraturan perundang-undangan, catatan-catatan resmi atau risalah dalam pembuatan undang-undang dan putusan-putusan hakim yang relevan dengan permasalahan dan tujuan penelitian. Terhadap bahanbahan hukum tersebut dilakukan klasifikasi secara sistematis sesuai rumusan masalah dan tujuan penelitian. Klasifikasi dimaksudkan untuk melakukan pemilahan bahan hukum berdasarkan tema-tema analisis yang relevan dan aktual.

\section{PEMBAHASAN}

\section{A. Prinsip Itikad Baik Pemerintah Melalui Repudiasi Kontrak UntukMencegah Wanprestasi Kontrak}

Perkembangan kontrak membawa kontrak kedalam dua aliran Teori 
Kontrak yang sering dijadikan rujukan, yaitu teori kontrak lengkap (complete contract) yang diasosiasikan dengan teori ekonomi kelembagaan (institusional theory) khususnya terkait dengan masalah principal agent dan teori kontrak tidak lengkap (incomplete contract) yang diasosiasikan dengan model transaction cost. ${ }^{2}$

Teori kontrak lengkap (Teroi Insentif), teori ini melihat permasalahan kontrak pengadaan sebagai persoalan insentif. Menurut Laffont dan Tirole, dalam model principal agents pemerintah sebagai principal dihadapkan pada masalah informasi yang asimetris karena tidak bisa mendapatkan beberapa informasi penting mengenai penyedia (agent), terutama terkait dengan usaha (effort) yang akan dilakukan oleh penyedia ${ }^{3}$. Dengan demikian masalah yang dihadapi pemerintah sebagai pembeli adalah bagaimana mendisain suatu insentif (skema kontrak) agar penyedia memberikan informasi atau mengadopsi perilaku sesuai keinginan pembeli. Dikaitkan dengan tahapan proses pengadaan, teori insentif lebih menitikberatkan pada disain kontrak sebelum kontrak ditandatangani.

Teori Kontrak Tidak Lengkap (Teori Biaya Transaksi), yang mengasumsikan bahwa para pihak dapat menuangkan hak dan kewajiban untuk seluruh kemungkinan yang akan terjadi, dalam teori biaya transaksi asumsi tersebut tidak berlaku. Pada kenyataannya hampir semua kontrak (termasuk kontrak pengadaan) merupakan kontrak yang tidak lengkap ${ }^{4}$. Ketidaklengkapan suatu kontrak tidak dapat dihindari sebagai

\footnotetext{
${ }^{2}$ Robin A.Suryo dan Agita M.Ulfa, Teori Kontrak dan Implikasinya Terhadap Regulasi Pengadaan Barang/Jasa Pemerintah, Jurnal Pengadaan, Vol 3 No 3, November, 2013, h.7

33 Ibid, lihat pada penjelasan Laffont, J.J dan Tirole J, A Theory of Incentives in Procurement and Regulation, Cambridge, Mass:MIT Press, Inggris.

${ }^{4}$ Lihat penjelasan Robin A.Suryo dan Agita M.Ulfa, Teori Kontrak dan Implikasinya Terhadap Regulasi Pengadaan Barang/Jasa Pemerintah menjelaskan Ben-Shahar (2004) dalam jurnalnya "Disagree:Filling Gaps in Deliberately Incomplete Contract" menyatakan bahwa secara definisi hukum sebuah kontrak tidak boleh tidak lengkap, karena agar institusi pengadilan dapat menegakkan kontrak, mereka harus memastikan bahwa ketentuan yang ada dalam kontrak cukup lengkap sehingga maksud dari para pihak dapat diketahui dan dipahami dengan jelas. Jika kontrak tidak lengkap maka institusi pengadilan akan mengisi kekosongan atau ketidaklengkapan ketentuan dalam kontrak. Dalam konteks ini maka kontrak selalu dianggap lengkap karena institusi pengadilan akan mengisi ketentuan yang tidak lengkap, atau jika tidak maka kontrak tersebut tidak
}

\section{3 | Pasca Sarjana Magister Hukum Universitas Borneo Tarakan}


akibat dari pertimbangan biaya transaksi yang mahal untuk membuat kontrak yang lengkap terutama biaya informasi (information costs), adanya rasionalitas yang terbatas (bounded rationality) atau ketidakmampuan untuk melihat atau memprediksi hal-hal yang bersifat kontinjen, dan oleh sebab lainnya. Dalam teori ini ketidaklengkapan suatu kontrak juga disebabkan oleh ketidakmampuan institusi yang bertanggungjawab untuk menjamin kinerja kontrak (yaitu institusi pengadilan), karena mereka tidak mampu menegakkan ketentuan yang sulit/tidak dapat diverifikasi. Karena teori ini beranggapan bahwa para penegak hukum juga memiliki bounded rationality, maka kinerja kontrak tidak dapat dijamin oleh mekanisme eksternal (lembaga pengadilan). Oleh Williamson kondisi seperti ini disebut sebagai kegagalan institusi. ${ }^{5}$

Teori biaya transaksi, sumber inefisiensi bersumber dari proses adaptasi atau penyesuaian yang harus dilaksanakan dalam pelaksanaan kontrak. Proses adaptasi ini juga dapat menimbulkan underinvestment atau overinvestment. Underinvestment terjadi ketika kewajiban para pihak tidak secara optimal dirumuskan dan dituangkan dalam kontrak, sehingga terdapat peluang untuk melakukan renegosiasi terkait dengan kewajiban tersebut pada saat pelaksanaan kontrak. Renegosiasi disini memberi celah bagi perilaku oportunistik, yaitu salah satu atau bisa jadi kedua belah pihak mencoba mengambil keuntungan dari proses renegosiasi yang biasanya cenderung mengakibatkan terjadinya underinvestment. Sebaliknya, kontrak yang tidak lengkap - ditambah dengan adanya ganti rugi (damage remedy) juga dapat berakibat pada investasi yang berlebihan (overinvestment). Karena kontrak mengharuskan salah satu pihak untuk melakukan investasi, sementara kondisi kontinjensi menghendaki bahwa lebih baik bagi pihak terkait untuk tidak melakukan investasi, maka

dapat diberlakukan. Oleh karena itu dalam teori legal, hukum menyediakan default rule yang mengisi celah dalam kesepakatan aktual dari para pihak. Default rule menjadikan kontrak tidak lengkap (incomplete contract) menjadi kontrak lengkap (complete contract)

5 Williamson, Transaction-Cost Economics; The Governance of Contractual Relations, Journal of Law adn Aconomics, Vol. 22, No 2, h. 233

\section{4 | Pasca Sarjana Magister Hukum Universitas Borneo Tarakan}


terjadi investasi yang tidak optimal (overinvestment).

Prinsip hukum memiliki makna yang sangat penting dalam sebuah sistem hukum. Prinsip hukum mempengaruhi sistem hukum positif dan menjelma dalam sistem yang dibentuk. Tidak ada sistem tanpa prinsip didalamnya ${ }^{6}$. Kaitannya dengan hukum kontrak, dikenal berbagai macam jenis prinsip hukum. Asser- Ruten mengajukan tiga prinsip hukum kontrak, yakni : konsensualisme, kekuatan mengikat perjanjian dan kebebasan berkontrak. Hoffman-Abas mengajukan prinsip kepatutan (billijkheids beginsel), sedangkan Nieuwenhuis mengajukan tiga prinsip yaitu : otonomi para pihak (Aotunomie-beginsel), kepercayaan (vertrouwens beginsel) dan prinsip causa (causa-beginsel). ${ }^{7}$ Wery mengedepankan prinsip itikad baik (geode trouw beginsel) ${ }^{8}$. Prinsip itikad baik dan keseimbangan akan menjadi kajian sentral pada penulisan ini.

Terkait dengan beberapa prinsip hukum yang berkembang secara bebas didalam praktek berkontrak, sebagaimana yang dikemukakan sebelumnya ada beberapa prinsip/asas hukum kontrak yang sering digunakan sebagai saka guru hukum kontrak, yaitu : ${ }^{9}$

1. Kebebasan Berkontrak

2. Konsensualisme

3. Pacta Sunt Servanda

4. Itikad Baik

5. Keseimbangan/ Proporsionalitas ${ }^{10}$

Menurut Niewenhuis asas/prinsip hukum itu berfungsi sebagai

\footnotetext{
${ }^{6}$ Y. Sogar Simamora, Hukum Kontrak , Prinsip-Prinsip Hukum Kontrak Pengadaan Barang dan Jasa Pemerintah di Indonesia, Laksbang Pressindo, Surabaya, 2017, h. 29

7 Ibid

8 Ibid

${ }^{9}$ Agus Yudha Hernoko, Hukum Perjanjian, Asas Proporsionalitas dalam Kontrak Komersil, Prenada Media Grup, Jakarta, 2014, h.107

${ }^{10}$ Lihat dalam hubungan antar asas-asas menurut Prof Agus Yudha Hernoko dalam bukunya Hukum Perjanjian, Asas Proporsionalitas dalam Kontrak Komersil mendudukan asas proporsionalitas sebagai asas atau sebuh prinsip yang mandiri dan berdiri setara dengan asas-asas pokok hukum kontrak yang lain. Asas keseimbangan yang dimaksud dalam kontrak lebih diarahkan pada keseimbangan sesuai porsi hak dan kewajiban masing-masing pihak.
}

105 | Pasca Sarjana Magister Hukum Universitas Borneo Tarakan 
pembanguan sistem, dan lebih lanjut asas-asas itu sekaligus membentuk sistem "check and balance". ${ }^{11}$ Sistem yang terbentuk ini harus terbentuk dari kesatuan semua prinsip hukum dan dijalankan dengan itikad baik sebagai prinsip utama yang dipegang kuat dan di jalankan secara seimbang dan adil/Propersional oleh kedua belah pihak.

Tidak banyak literatur mengenai Repudiasi Kontrak ini, istilah repudiasi ini masih jarang terdengar walaupun dalam praktiknya Repudiasi kerap kali terjadi. Menurut sejarahnya doktrin dari teori repudiasi/ Anticipatory repudiation is relatively old, having its origin in the common law ${ }^{12}$. Doktrin lama yang berasal dari common law yang berkembang di negara-negara Eropa. Repudiasi yang berkembang sejak lama ini seringkali dikaitkan dengan teoripembatalan perjanjian secara sepihak. Repudias (repudiation anticipatory) adalah pernyataan mengenai ketidaksediaan atau ketidakmampuan untuk melaksanakan perjanjian yang sebelumnya telah disetujui, pernyataan mana disampaikan sebelum tiba waktu melaksanakan perjanjian tersebut ${ }^{13}$. Repudiasi dalam pengertian itu disebut repudiasi anticipatory yang berbeda dengan repudiasi biasa yaitu pembatalan yang dinyatakan ketika telah memasuki masa pelaksanaan perjanjian.

Konsekuensi hukum yang timbul akibat adanya repudiasi ini atas suatukontrak adalah dapat menunda atau bahkan dapat membatalkan pihak lain dari kewajiban melaksanakan prestasi dari perjanjian tersebut; dan disisi lain memberikan hak kepada pihak yang lain apa yang menjadi haknya, sungguhpun kepada pihak yang melakukan repudiasi belum jatuh tempo untuk melaksanakan kewajibannya berdasarkan perjanjian. ${ }^{14}$ Jika kita cermati lebih lanjut, dalam praktik pelaksanaan repudiasi nantinya

\footnotetext{
11 Prof. Agus Yudha Hernoko, Op. Cit, h.25

12 12Alphonse M.Squillante, Anticipatory Repudiation and Retraction, Valparaiso University Law Review, Vol 7 No 3, Produced by The Berkeley Electronic Press, 1973, h.377

13 Munir Fuady, Hukum Kontrak: Dari Sudut Pandang Hukum Bisnis, PT. Citra Aditya Bakti, Bandung, tahun 2001, h.105

${ }^{14}$ Munir Fuady, Op.Cit, h.103
}

106 | Pasca Sarjana Magister Hukum Universitas Borneo Tarakan 
konsekuensi hukum disisi pemerintah tentunya berbeda dengan pihak penyedia. Konsekuensi hukum dari pihak pemerintah jika ditinjau dari konsekuensi umum repudiasi adalah sebagai berikut:

1. Menunda pelaksanaan kontrak jika kontrak belum sempat dilaksanakan sampai batas waktu yang dirasa cukup oleh pemerintah misalnya, di laksanakan pada tahun anggaran perubahan (masih masuk dalam tahun anggaran yang sama), namun apabila kontrak telah berjalan, dengan kesepakatan pembayaran sampai pada progres pekerjaan yang dilaksanakan saja, kemudian dilakukan repudiasi dalam adendum kontrak untuk dilaksanakan sampai pada batas waktu yang dirasa cukup oleh pemerintah.

2. Membatalkan pelaksanaan kontrak (Biasa disebut putus kontrak) dengan pertimbangan hukum dan rekomendasi dari pejabat berwenang terkait (Inspektur Daerah/APIP, Biro Hukum daerah dan Deputi Bidang Sanggah LKPP Dit. Penanganan Masalah Hukum) kemudian dituangkan dalam bentuk Surat Keputusan Walikota untuk tingkat kota, Gubernur untuk tingkat provinsi dan seterusnya sesuai kewenangan yang melekat.

Konsekuensi hukum untuk pihak penyedia jika pemerintah melakukan repudiasi adalah sebagai berikut :

1. Jika penyedia menyetujui kontrak ditunda maka harus dipastikan dengan benar ditunda sampai batas waktu yang bisa dipastikan. Untuk progres pekerjaan yang telah dilaksanakan harus juga dipastikan dibayar agar tidak terjadi kerugian.

2. Jikapun kontrak dibatalkan oleh pemerintah, penyedia bisa menerima dengan catatan tidak ada kerugian yang ditimbulkan atau kalaupun ada kerugian, penyedia harus memastikan pemerintah melaksanakan kewajibannya terlabih dahulu baru kemudian memutuskan kontrak. 
3. Kalau sampai pada akhirnya, penyedia tidak menyetujui repudiasi oleh pemerintah maka Penyedia dipersilahkan menempuh jalur hukum di pengadilan perdata atau arbitrase.

Adapun alasan terhadap diperkenankannya suatu tuntutan ganti rugi yang lebih awa jika terjadi repudiasi adalah sebagai berikut :

a. Posisi yang lebih awal

Sudah barang tentu sangat diperlukan suatu posisi yang lebih awal dalam suatu proses hukum sehingga proses penyelesaian secara hukum dapat lebih optimal. Dengan lebih awal ditetapkannya pemberitahuan ganti rugi dalam suatu repudiasi, maka konsekuensinya menjadi sebagai berikut :

- Mencari saksi lebih mudah, karena masih hidup atau belum berpindah tempat.

- Pengetahuan dan dokumen tentang kontrak tersebut masuh fresh.

b. Alasan kepastian hukum

Kepastian hukum juga menjadi alasan mengapa suatu ganti rugi dalam repudiasi dapat diberikan lebih awal, yakni pada saat belum jatuh temponya pelaksanaan prestasi dari pihak yang melakukan repudiasi. Sehingga dengan demikian pihak yang dirugikan oleh tindakan repudiasi ini dapat segera mengambil sikap apakah misalnya membuat kontrak pengganti dengan pihak lain, melakukan litigasi atas kerugiannya.

Perjalanan kontrak pengadaan barang/jasa yang dilakukan Pemerintah tentu saja dari sisi Pemerintah bertanggung jawab menjamin kelancaran berlangsungnya pembangunan. Untuk itu setiap proyek pemerintah meskipun terjadi hambatan apapun bahkan keadaan kahar sekalipun, karena sudah dianggarkan dan proses penganggaran bukanlah sebuah proses sederhana namun melewati proses panjang tidak akan mungkin tidak terbayar. Pasti terbayar. Hanya saja Pemerintah memiliki beberapa instrument salah satunya melalui 
repudiasi anticipatory dimana sebelum masa kontrak habis pemerintah kembali mengajak penyedia untuk melakukan negosiasi. Isi negosiasi beragam, mulai dari dihentikannya kontrak dan dibayar sesuai progress pekerjaan (mengikuti ketentuan kontrak kritis) atau kegiatan akan dibayarkan pada anggaran tahun kemudian.

Jika dilihat dari sisi jenis kontrak tahun tunggal yang tidak boleh melewati tahun anggaran berjalan negosiasi bisa saja dilakukan dengan menyelesaikan pekerjaan sebelum tahun anggaran berakhir dan pembayaran dilakukan di tahun anggaran berikutnya. Semua kesepakatan apapun yang didapat dalam negosiasi harus tertuang dalam berita acara dan dibuat addendum kontrak yang menjadi satu kesatuan yang tak terpisahkan dari dokumen kontrak. Atas dasar inilah sesuai addendum kontrak repudiasi atau pernyataan tidak sanggup melaksanakan kontrak oleh pemerintah bukan menjadi wanprestasi namun menimbulkan sebuah prestasi baru dan membatalkan prestasi lama. Hal ini diatur juga dalam syarat-syarat umum kontrak sesuai Peraturan Lembaga dan Peraturan Menteri tentang standar dan pedoman pengadaan barang/jasa pemerintah melalui penyedia.

B. Prinsip Keseimbangan Dalam Pelaksanaan Repudiasi Kontrak Pengadaan Barang/ Jasa Pemerintah

Tidak ada aturan baku tentang prosedur atau tata cara pelaksanaan repudiasi kontrak karena repudiasi kontrak merupakan sebuah pernyataan kehendak pihak yang bermaksud untuk melakukan langkah antisipatif dikarenakan ketidakmampuan salah satu pihak untuk meneruskan kontrak. Dalam praktek pengadaan istilah repudiasi sangat jarang terdengar bahkan sangat sedikit sekali literatur tentang repudiasi padahal repudiasi ini sudah sering terjadi secara tidak sadar dalam sebuah negosiasi kontrak. Bisa dikatakan bahwa repudiasi lahir di masa negosiasi pengendalian kontrak. Mekanisme Repudiasi

\section{9 | Pasca Sarjana Magister Hukum Universitas Borneo Tarakan}


merunut pada masa pengendalian kontrak :

a. Pemerintah melakukan kajian mendalam internal bersama unsur-unsur terkait seperti inspektorat, biro hukum dan koordinasi ke Lembaga Kebijakan Pengadaan Barang dan Jasa.

b. Setelah mendapat rekomendasi dan masukan yang diperlukan, semua masukan tersebut dituangkan dalam bentuk tertulis berupa MoU (Memory of Understanding), atau bisa juga Surat Rekomendasi disesuaikan dengan nominal besaran nilai pengadaan/proyek yang dihadapi bahwa ketiga institusi telah sepaham akan duduk permasalahannya penyelesaiannya.

c. Kemudian, pemerintah mengundang Penyedia dan melaksanakan rapat pembuktian atau Show Case Meeting/SCM. Disinilah terjadi negosiasi repudiasi. Jika penyedia sepaham dan menyetujui repudiasi maka dilakukan langkah-langkah sesuai konsekuensi hukum yang dijelaskan pada pembahasan sebelumnya. Jika repudiasi ini ditolak oleh pihak penyedia yang merasa dirugikan maka pihak penyedia dapat menuntut haknya/ganti rugi yang layak dengan mengajukannya di muka pengadilan.

Hasil dari negosiasi repudiasi dapat berupa pengehentian kontrak tentu saja harus ada addendum yang didukung dengan Berita Acara Adendum diperkuat oleh Surat Keputusan Pejabat Berwenang. Kontrak bisa saja dihentikan/dibatalkan sesuai dengan konsekuensi hukumnya apabila terjadi keadaan :

1. Force Mejeur/Keadaan Kahar/Overmact/Keadaan memaksa, terdapat dalam rumusan Pasal 1244 KUHPerdata, Pasal 1245 KUHPerdata, 1444 KUHPerdata, 1445 KUHPerdata, dengan dalil:

a. Pemenuhan prestasi terhalang atau tercegah

b. Terhalangnya pemenuhan prestasi tersebut diluar kesalahan pemerintah

c. Peristiwa yang menyebabkan terhalangnya prestasi 
tersebut bukan merupakan risiko pemerintah.

Sesuai Teori Objetif 15 bahwa prestasi yang tidak mungkin bagi setiap orang artinya terkait dengan ketidakmungkinan mutlak bagi setiap orang (Pasal 1444 KUHPerdata) bisa saja terjadi bencana alam dan bencana non alam seperti wabah penyakit. Penghentian Kontrak karena keadaan kahar dilakukan secara tertulis oleh Pejabat Penandatangan Kontrak dengan disertai alasan penghentian pekerjaan. Penghentian kontrak karena keadaan kahar dapat bersifat:

a. Sementara hingga Keadaan Kahar berakhir; atau

b. Permanen apabila akibat keadaan kahar tidak memungkinkan dilanjutkan/diselesaikannya pekerjaan.

Jika penghentian kontrak bersifat sementara maka kontrak dapat dilanjutkan sesuai kesepakatan setelah keadaan kahar berkahir. Dalam hal Kontrak dihentikan karena keadaan kahar, maka Pejabat Penandatangan Kontrak wajib membayar kepada Penyedia sesuai dengan kemajuan hasil pekerjaan yang telah dicapai setelah dilakukan pemeriksaan bersama atau berdasarkan hasil audit.

2. Keadaan Sulit (Hardship)

Keadaan sulit merupakan perkembangan doktrin baru yang berkembang terkait dengan hambatan atau kendala dalam pelaksanaan kontrak. Berbeda dengan overmacht yang diatur dalam Buku III KUHPerdata, maka keadaan sulit belum diatur meski pada umumnya kebanyakan hakim memutuskan keadaan sulit masuk menjadi keadaan overmacht.

Apapun keadaan kontrak yang tidak memungkinkan untuk kontrak dilaksanakan sesuai yang diperjanjikan hingga kontrak berakhir harus dapat dibuktikan dengan Peraturan Pemerintah atau putusan pengadilan yang menyatakannya telah terjadi. Namun apabila pekerjaan telah selesai

\footnotetext{
15 Lihat penjelasan Teori Objektif Prof. Dr. Agus Yudha Hernoko dalam bukunya Hukum Perjanjian Asas Proporsionalitas dalam Kontrak Komersil.
}

\section{1 | Pasca Sarjana Magister Hukum Universitas Borneo Tarakan}


dan hak dan kewajiban para pihak yang terdapat dalam Kontrak sudah terpenuhi. Terpenuhinya hak dan kewajiban para pihak adalah terkait dengan pembayaran yang seharusnya dilakukan akibat dari pelaksanaan kontrak. Sebagai contoh meskipun kontrak telah berhenti karena pekerjaan telah selesai $100 \%$ (seratus persen) namun kontrak belum berakhir apabila masih terdapat sisa pembayaran yang belum dibayarkan oleh PPK kepada Penyedia. Misalnya pembayaran atas sisa pekerjaan akibat keterlambatan yang melewati tahun anggaran atau pembayaran atas penyesuaian harga.

Asas keseimbangan merupakan suatu keadaan dimana para pihak yang terlibat dalam kontrak harus memiliki kedudukan atau posisi yang seimbang, tidak ada yang mendominasi, dan juga para pihak memiliki posisi tawar yang seimbang, baik dari kedudukan para pihak, kepentingan maupun hak dan kewajiban para pihak. Dalam suatu kontrak, kepentingan individu dan masyarakat akan bersamaan dijamin oleh hukum objektif. Asas keseimbangan dilandaskan pada upaya mencapai suatu keadaan yang seimbang. Tidak terpenuhinya keseimbangan, dalam konteks asas keseimbangan, bukan semata untuk menegaskan fakta dan keadaan, melainkan lebih daripada itu berpengaruh terhadap kekuatan yuridikal kontrak dimaksud. Dalam terciptanya atau terbentuknya suatu kontrak, ketidakseimbangan bisa muncul sebagai akibat dari perilaku para pihak itu sendiri ataupun sebagai konsekuensi dari substansi (muatan isi) kontrak atau pelaksanaan kontrak. Kontrak harus segera ditolak saat itu juga, apabila tampak bahwa kedudukan salah satu pihak terhadap pihak lainnya adalah lebih kuat atau dominan, dan kedudukan tidak seimbang ini dapat mempengaruhi cakupan muatan isi maupun maksud dan tujuan dibuatnya kontrak.

Akibat ketidaksetaraan prestasi dalam kontrak adalah ketidakseimbangan. Jika kedudukan lebih kuat tersebut berpengaruh

\section{2 | Pasca Sarjana Magister Hukum Universitas Borneo Tarakan}


terhadap perhubungan prestasi satu dengan lainnya, dan hal mana mengacaukan keseimbangan dalam kontrak, dalam hal ini terhadap perhubungan prestasi satu dengan lainnya, dan hal mana mengacaukan bagi pihak yang dirugikan akan merupakan alasan untuk mengajukan tuntutan ketidakabsahan kontrak. Sepanjang prestasi kontrak mengandaikan kesetaraan, maka bila terjadi ketidakseimbangan, perhatian akan diberikan terhadap kesetaraan yang terkait pada cara bagaimana kontrak terbentuk, dan tidak pada hasil akhir dari prestasi yang diatur dalam kontrak.

Prinsip keseimbangan berkontrak antara penyedia dengan pemerintah seringkali selalu berbenturan dengan kewenangan dan kekuasaan pemerintah. Topik yang menjadi bahasan utama dalam kontrak yang melibatkan pemerintah sebagai pihak adalah menyangkut adanya semacam rancangan kontrak yang telah dibuat diawal sebelumnya sebelum kesepakatan antara kedua belah pihak dan kekebalan pemerintah manakalah digugat di muka pengadilan serta pemeritah memiliki suatu imunitas yang dapat digunakan manakalah sekiranya kontrak tidak dapat dipenuhi sebelah pihak oleh pemerintah sendiri.

Telah diuraikan sebelumnya bahwa ketika pemerintah memasuki hubungan kontraktual dalam skala privat, pemerintah mempunyai peran ganda (double role). Disatu sisi pemerintah kedudukannya seperti subyek privat lain, tetapi disisi lain kedudukannya sebagai badan public tidak terlepaskan. Ketika pemerintah menjalin perikatan dalam skala privat maka sejak itu harus dinilai pemerintah menyatakan tunduk pada aturan privat dalam situasi ini berlakulah segala konsekuensi hukum yang timbul akibat hubungan yang dibentuk itu yaitu konsekuensi berlakunya prinsip dan aturan hukum dalam hukum perdata baik yang bersifat materil maupun formil.

Kata "sepakat" merupakan syarat pertama dalam pembentukkan kontrak. Terhadap kontrak pemerintah termasuk kontrak kerja konstruksi

\section{3 | Pasca Sarjana Magister Hukum Universitas Borneo Tarakan}


maupun kontrak pengadaan berlaku aturan seperti pada kontrak hukum privat yang tunduk pada prinsip dan aturan umum tentang hukum perikatan yang terdapat dalam Bab I sampai Bab IV Buku III KUHPerdata.

\section{PENUTUP}

\section{A. Kesimpulan}

Prinsip itikad baik pemerintah melalui repudiasi kontrak untuk mencegah wanprestasi kontrak yang dilakukan melalui usaha-usaha pemerintah khususnya dengan melaksanakan repudiasi kontrak untuk mencegah wanprestasi kontrak merupakan sebuah prestasi kontrak dengan dasar perubahan kontrak yang telah dinegosiasikan sebelumnya atau dengan istilah addendum kontrak. Langkah pemerintah menyelamatkan kontrak dari kegagalan adalah suatu keharusan mengingat kontraktor atau penyedia barang/jasa adalah masyarakat yang menjadi rekanan pemerintah yang hak-hak nya harus dijamin.

Pemerintah tidak diperkenankan bertindak seolah-olah penyedia yang membutuhkan pemerintah saja namun pemerintah juga bergantung pada penyedia. Ada ikatan simbiosis yang tercipta dari pengadaan barang/jasa pemerintah ini. Sebaliknya masyarakat juga harus sama-sama mendukung pemerintah dalam proses pembangunan demi mewujudkan tujuan pengadaan barang/jasa yang nantinya juga berguna bagi masyarakat luas.

Prinsip keseimbangan dalam pelaksanaan repudiasi kontrak pengadaan barang/ jasa pemerintah merupakan salah satu asas dalam hukum kontrak telah dicoba kembali di ramu dalam peraturan Pengadaan Barang/Jasa Pemerintah yang baru. Hal ini terlihat dari kontrak pengadaan barang/jasa bagi keperluan pemerintah, secara normatif yang mana pada Perpres Nomor 16 Tahun 2016 sudah diatur dengan jelas mengenai ketentuan sanksi bagi PA/ KPA/ PPK/ Pejabat Pengadaan/ Pokja Pemilihan/ PjPHP/ PPHP maupun sanksi bagi penyedia barang/jasa (Pihak II) melakukan cidera janji. Khusus untuk praktek Repudiasi secara empiris hal tersebut tidak disebutkan secara langsung dalam kontrak pengadaan barang/jasa meskipun dalam prosesnya terkadang bisa saja Repudiasi

\section{4 | Pasca Sarjana Magister Hukum Universitas Borneo Tarakan}


itu hadir melalui berbagai macam bentuk progresifnya, ada berupa surat penundaan pembayaran oleh pemerintah hingga diputusnya kontrak. Namun tetap sebagai pihak yang memiliki hak dan kewajiban yang seimbang dalam kontrak perubahan kontrak rentan terjadinya resiko pelanggaran hukum.

\section{B. Saran}

Langkah pemerintah sebagai pihak yang membutuhkan barang dengan prinsip itikad baik dalam menanggulangi resiko gagal kontrak dan wanprestasi harus diapresiasi. Pemerintah dengan segala daya dan upaya sedemikian rupa menyelamatkan kontrak-kontrak agar tidak merugikan pihak penyedia. Namun memang dalam hal ini, perlu penyempurnaan dan penyederhanaan aturan standar dokumen pengadaan. Diharapkan kedepannya khusus dalam pelaksanaan Repudiasi Kontrak sesuai dengan prinsip itikad baik menjadi jalan keluar yang tidak menimbulkan kerugikan bagi pihak manapun, dan Repudiasi Kontrak ini dapat dituangkan secara redaksional ke dalam isi kontrak dengan syarat akan dipergunakan jika benar-benar terjadi keadaan yang dipersyaratkan.

Prinsip Keseimbangan Proporsional dalam mekanisme Repudiasi harus dilaksanakan dengan kesadaran akan hak dan kewajiban masing-masing pihak serta pihak penyedia harus sungguh-sungguh paham bahwa Pemerintah sebagai perpanjangan tangan Pemerintah melaksanakan Repudiasi tentunya dengan pertimbangan panjang dan selalu mengedepankan asas itikad baik serta pemenuhan keadilan. Repudiasi harus dilaksanakan jika memang sungguhsungguh dalam keadaan yang diperbolehkan oleh hukum dengan mekanisme yang terbuka dan transparan sesuai prinsip-prinsip pengadaan dan prinsip hukum kontrak.

\section{DAFTAR PUSTAKA}

Darwanto, Rahmad, Praktek Pelaksanaan Tender Pengadaan Barang dan Jasa Pemerintah dan Prinsip-Prinsip serta Etika yang Mendasarinya, Citra Aditya Bakti, Bandung, 2013

115 | Pasca Sarjana Magister Hukum Universitas Borneo Tarakan 
Fuady Munir, Hukum Kontrak: Dari Sudut Pandang Hukum Bisnis, PT.Citra

Aditya Bakti, Bandung, Tahun 2001

Fuady Munir, S.H.,M.H.,LL.M, Konsep Hukum Perdata, PT Rajagrafindo Persada, Jakarta, 2014

Hadjon, Philipus M, et.al., Pengantar Hukum Administrasi Indonesia, GajahMada University Press, cet.VIII, Yogyakarta 2002

Herwanto, Aspek Yuridis Dalam Pelaksanaan Tahapan Prosedur Pengadaan Barang dan Jasa Pemerintah, Mitra Ilmu, Surabaya, 2009

HS. Salim, Hukum Kontrak, Teori \& Teknik Penyusunan Kontrak, Sinar Grafika, Jakarta, 2008J. Satrio, Hukum Perikatan, Perikatan yang lahir dari perjanjian, buku II, Citra Aditya Bakti, Bandung, 1994

Kansil, S.T.C, Modul Hukum Perdata, Pradnya Paramita, Jakarta, 1991

Marzuki, Peter Mahmud, Penelitian Hukum, Kencana Prenada Media Group, Jakarta, 2008Muhammad, Yulian, Menyehatkan Pengadaan Barang dan Jasa Pemerintah Dalam Praktek, Rajawali Press, Jakarta, 2011

Rusli Harjdijan, Hukum Perjanjian Indonesia dan Common Law, cetakan ke-2, PT. Midyas Suryo Grafindo, Jakarta, 1994

Salim, HS, Hukum Kontrak Teori \& Teknik Penyusunan Kontrak, Sinar Grafika, Jakarta, 2013

Subekti, R, Aspek-Aspek Hukum Perikatan, Alumni, Bandung, 1986

Sutedi, Adrian, Aspek Hukum Pengadaan Barang dan Jasa dan Berbagai Permasalahannya, Sinar Grafika, Jakarta, 2008

Subianto, Arifin, Kedudukan Pejabat yang Berwenang dalam Pengadaan Barang Dan Jasa Pemerintah Berdasarkan Perpres No. 54 Tahun 2010i, Citra Aditya Bakti Bandung, 2012

Simamora, Sogar, Hukum Perjanjian, LaksBang Pressindo, Surabaya, 2009 
Simamora, Sogar, Hukum Kontrak Prinsip-Prinsip Hukum Kontrak Pengadaan Barang dan Jasa Pemerintah di Indonesia, LaksBang Pressindo, Surabaya, 2017

\section{Disertasi}

Utoyo. Bambang, Prinsip Proporsionalitas Dalam Kontrak Pengadaan Barang dan Jasa Pemerintah, Program Doktor Ilmu Hukum, Universitas

Airlangga, 2015

\section{Tesis}

Ariyono, Eko, Pembayaran Kontrak Pengadaan Barang dan Jasa Yang Melewati Tahun Anggaran, Program Magister Hukum, Universitas Airlangga, 2017

Cahyadi, Annang, Penyesuaian Harga, (Price Adjustment) Dalam KontrakPengadaan Barang dan Jasa Pada BUMN (Persero),Program Magister Hukum, Universitas Airlangga, 2018

\section{Jurnal}

Atmasasmita, Romli, Tiga Paradigma Hukum Dalam Pembangunan Nasional, Jurnal Hukum Prioris, Vol 3, No. 1, 2012

Purwanto Harry, Keberadaan Asas Pacta Sunt Servanda Dalam Perjanjian Internasional, Mimbar Hukum, Vol 21, No 1, 2009

Mariyati Dwi, Prinsip Hukum Dalam Penyusunan Dan Pelaksanaan Kontrak Engineering Procurement Construction (Kontrak "EPC"), Yuridika, Vol 33 No. 2, 2018 